\title{
Conflict Between Coastal Tourism Development and Sustainability: case of Mostaganem, Western Algeria
}

\author{
Dr. Nasr-Eddine Taibi ${ }^{1}$
}

\begin{abstract}
Dependency on oil and gas incomes has urged Algeria to support tourism development as a means of creating other sources of wealth. However, this is not done without environmental damages. Indeed, the insufficient number of host accommodations at the coastal areas has led to chaotic construction projects. Mostaganem is an example. It attracts recently 11 million tourists yearly, although it lacks in host accommodation. To overcome this issue, new tourist infrastructures close to the shoreline and among the coastal dunes have been programed regardless of the Littoral law that protects the coastal strip $(300 \mathrm{~m})$. Moreover, the wastewater issue is neither discussed nor solved, in spite of a lack of wastewater treatment plants in this area. This work is based on data collected from the Algerian Government, and the Ministry of Land-use Planning, Tourism, and Handicraft. Shore urbanization endangers the sustainability of the beaches as a socioeconomic resource. Seaside tourism could be developed without any beach urbanization by constructing in the nearby coastal rural municipalities. Tourists would enjoy the beach during the day and would return to their accommodation in the rural municipality. This would benefit economically both the local population and the environment.
\end{abstract}

Key words: Coastal tourism, Construction, Littoral law 02/2002, Sustainability, Socioeconomic, Mostaganem, Algeria.

\section{Introduction}

Coastal resources and tourism in Algeria are under development, although they represent an important natural, cultural and economic potential (Bouadam 2011). The seaside tourism is an important economic asset for the South Mediterranean countries, as Morocco and Tunisia; in Algeria is just the use of the beach and bathing area during the summer holidays. After the independence in 1962, seaside tourist accommodations existed only in main cities (Algiers, Oran and Annaba). Since, Algeria neglected the tourism as a source of revenues. Between 2004 and 2013, the touristic activities brought just an annual average of US\$ 623 million (Ministry of Land-use Planning, Tourism, and Handicraft 2015). Nowadays, the Algerian tourism sector is in a contradictory situation: an attractive image and interesting opportunities for the development of touristic activities against a deficit in accommodation capacity, marketing, and hostelry experience. The consequence was the worst position of the country in the list of the best-targeted tourist destinations in Africa (Bouadam 2011). According to the National Informatics and Statistics Centre (CNIS 2015), the oil and gas revenues are currently insufficient to guarantee the import of essential commodities and technical services. With regard to the 
actual economic situation, the Algerian Government is supporting tourism development concretely using the already existing National Tourism Development Plan (SDAT 2008). In the haste, construction projects have been authorized without the necessary environmental impact assessment. The construction of host accommodations has been authorized to close to the shoreline in Algeria, although it is illegal (Littoral Law 022002). Moreover, the available wastewater treatment plants are insufficient for the programmed tourist infrastructures (Directorate of Water Resources, 2015). For these reasons, the coastline urbanization founded exclusively on economic interests is prejudicial to the coastal environment. Moreover, the construction among coastal dunes increases beach erosion over the long term and leads to the loss of tourism attraction (Phillips \& Jones 2006). According to Blancas et al. (2011), the development of increasing tourist activity should be reconciled with the protection of natural and cultural resources that support such activity. Nowadays, coastal development should be responsible and sustainable to protect a decent economic policy. In this respect, the paper focuses on the Eastern coast of Mostaganem, as an example, which could be economically developed without any shore urbanization. The rural municipalities of this area provide extensive natural beaches, cultural heritage, agriculture, and fishing activities. These are excellent predispositions for the development of sustainable tourism within these municipalities.

\section{Study area and actual tourism situation}

The study is based on data collected from the Ministry of Land-use Planning, Tourism, and Handicraft (2015), the National Informatics and Statistics Centre (CNIS 2015), and the National scheme of Land-use Planning for 2015-2025 (SDAT 2008). Technical data related to the beaches and the rural municipalities they belong to, have been obtained from the Directorate of Environment (2015), and the Directorate of Water Resources (2015). The coastline length and the distance beach-rural municipality have been determined using Google Earth Pro (version 7.1.5.1557). The Province of Mostaganem (124 km coastline) is situated in the West of Algeria. The Oued Cheliff River separates this Province in a Western and an Eastern part (Fig. 1). The main tourism activity is established in Sablettes, a tourist site of the Western coast, which is heavily built-up; the majority of its host structures is built among the dunes (Fig. 2). Nevertheless, constructions are programmed regardless of the Littoral Law 02/2002, which protects the beaches, the fore dunes, and the backshore. In contrast, the Eastern coast of Mostaganem experienced no significant urbanization to date. 


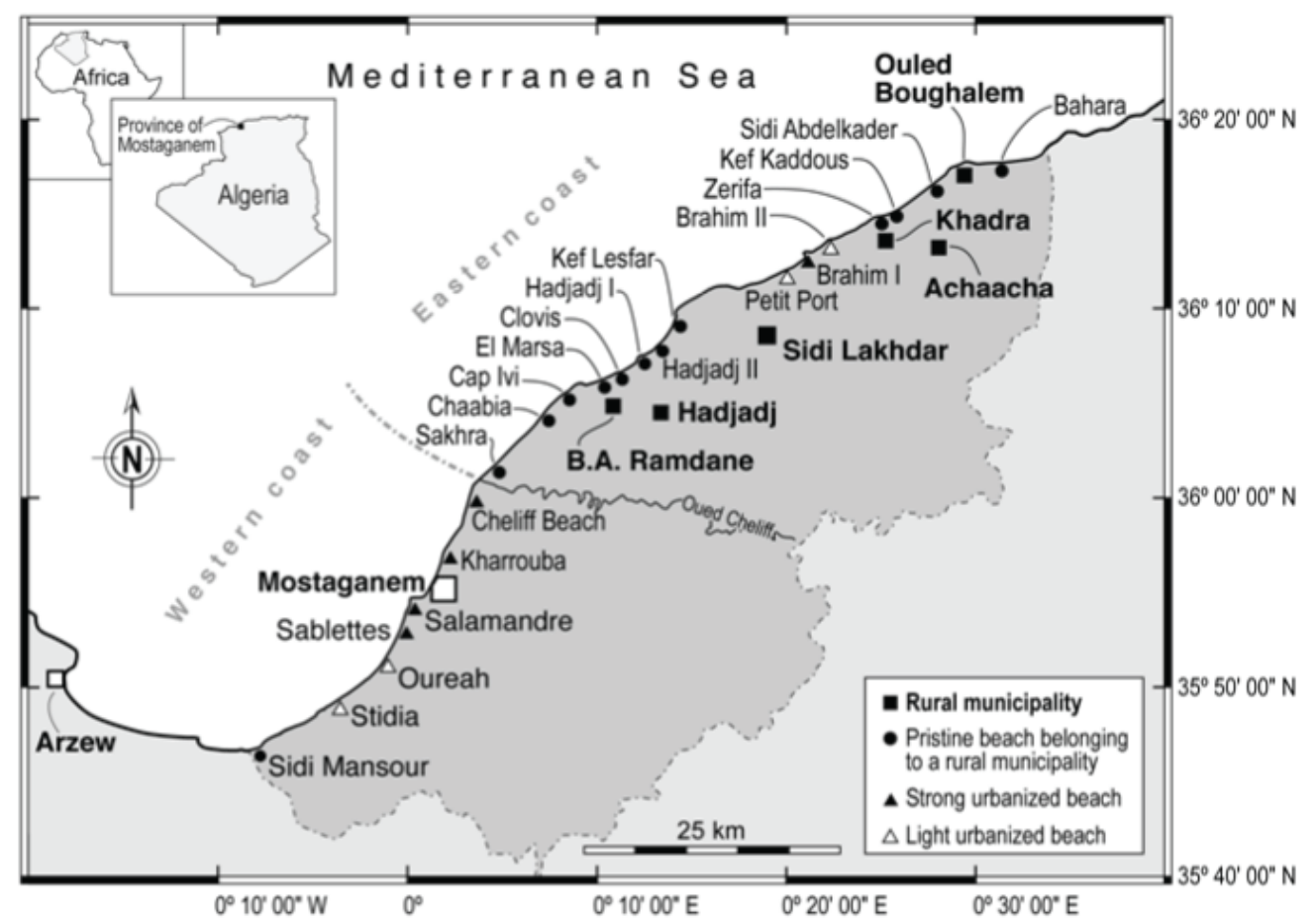

Fig. 1: Coastal zone of Mostaganem (rural municipalities, pristine and urbanized beaches).
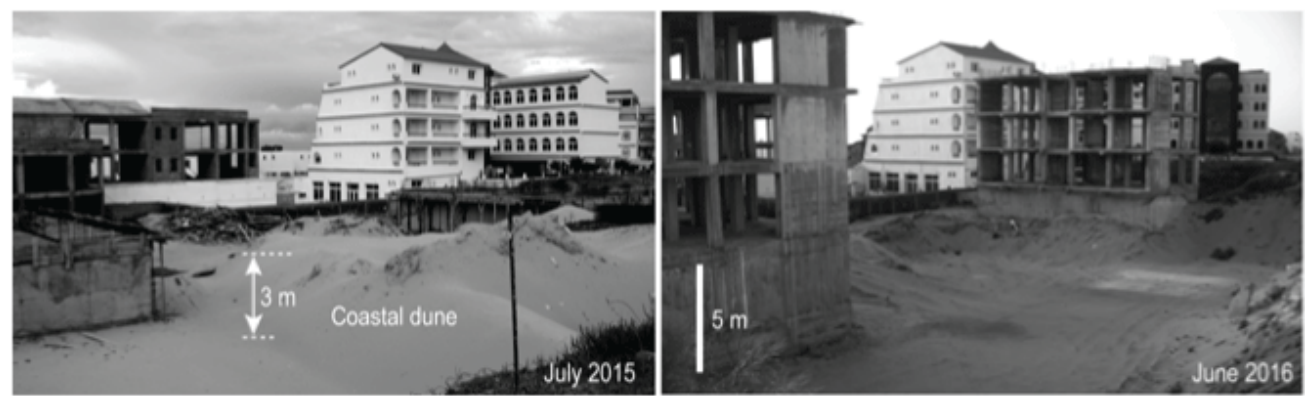

Fig. 2: Accommodation built among the coastal dunes in Sablettes (Western coast).

Approximately 11 million Algerian tourists spend yearly their summer holidays in Mostaganem. However, the offer doesn't satisfy the demand; 1 bed for 1000 tourists during the summer 2015 (Ministry of Land-use Planning, Tourism, and Handicraft 2015). The high demand leads the Province of Mostaganem to increase the number of host structures. Between 2004 and 2014, the accommodation number experienced a slight growth $(2 \%)$ although the number of tourists increased considerably (33\%; Fig. 4). During the period 2011-2014, only 134 beds have been created (Table 1). 


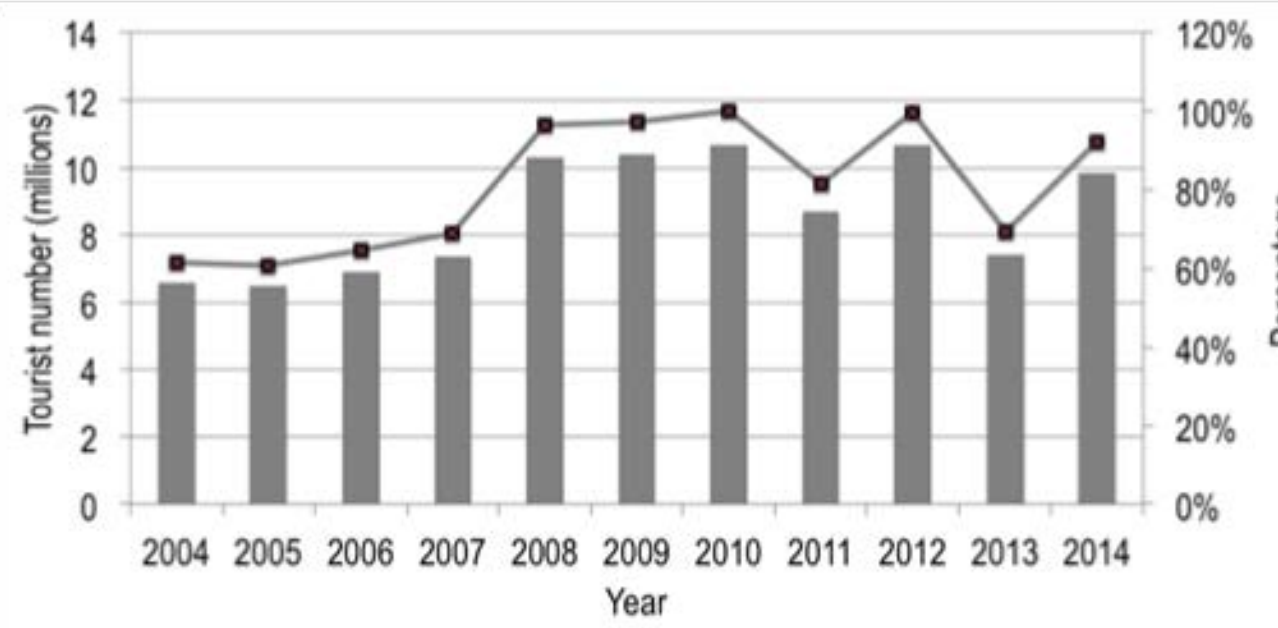

Fig. 4: Tourist number in Mostaganem (2004 - 2014; Civil Protection of Mostaganem 2015).

Table 1-Evolution of the tourist accommodation number in Mostaganem (2011-2014)

\begin{tabular}{|l|l|l|l|l|}
\hline \multirow{2}{*}{ Hosting structure (H.s.) } & \multicolumn{2}{|l|}{2011} & 2014 \\
\cline { 2 - 5 } & Number of H.s. & Number of beds & Number of H.s. & Number of beds \\
\hline Seaside & 14 & 1.278 & 15 & 1.340 \\
\hline Urban & 8 & 390 & 9 & 462 \\
\hline Holidays centres & 30 & 7.916 & 30 & 7.916 \\
\hline Youth hostels & 6 & 1.255 & 6 & 1.255 \\
\hline Total & $\mathbf{5 8}$ & $\mathbf{1 0 . 8 3 9}$ & $\mathbf{6 0}$ & $\mathbf{1 0 . 9 7 3}$ \\
\hline
\end{tabular}

Source: Ministry of Land-use Planning, Tourism, and Handicraft (2015).

\section{Coastal use conflicts}

\subsection{Tourist accommodation projects in Mostaganem}

As mentioned above, in contrast to the Western coast of Mostaganem, the Eastern one experienced no significant coastline urbanization; it provides pristine beaches, an impressive dune landscape, and extensive natural areas. These valuable resources belong to six rural municipalities namely Ben Abdelmalek Ramdane (B.A. Ramdane), Hadjadj, Sidi Lakhdar, Khadra, Achaacha, and Ouled Boughalem, located a few $\mathrm{km}$ from the shore. The Eastern coast could contribute to its own socioeconomic development by creating a sustainable tourism adapted to natural resources. The Touristic Expansion Zones (TEZ) created by the Algerian Government in Mostaganem (Decree 88-232 1988; Decree 10-131 2010) are favourable for the seaside tourism development (Law 2003-01 2003). Unfortunately, the decision maker acted in haste and authorized the construction of 2.136 beds in the pristine TEZ of Cap Ivi (Fig. 5) close to 
the coastline and over 102 ha (Executive Decree $n^{\circ} 13-128$ 2013; Fig. 6). In the TEZ of Ben Abdelmalek Ramdane, 4.000 beds are programmed too on the shore over 166 ha (Executive Decree $\mathrm{n}^{\circ}$ 13-128 2013). Ecologic sites as Cap Ivi should be protected because they could be an attractive promotional image of the seaside tourism in Mostaganem.

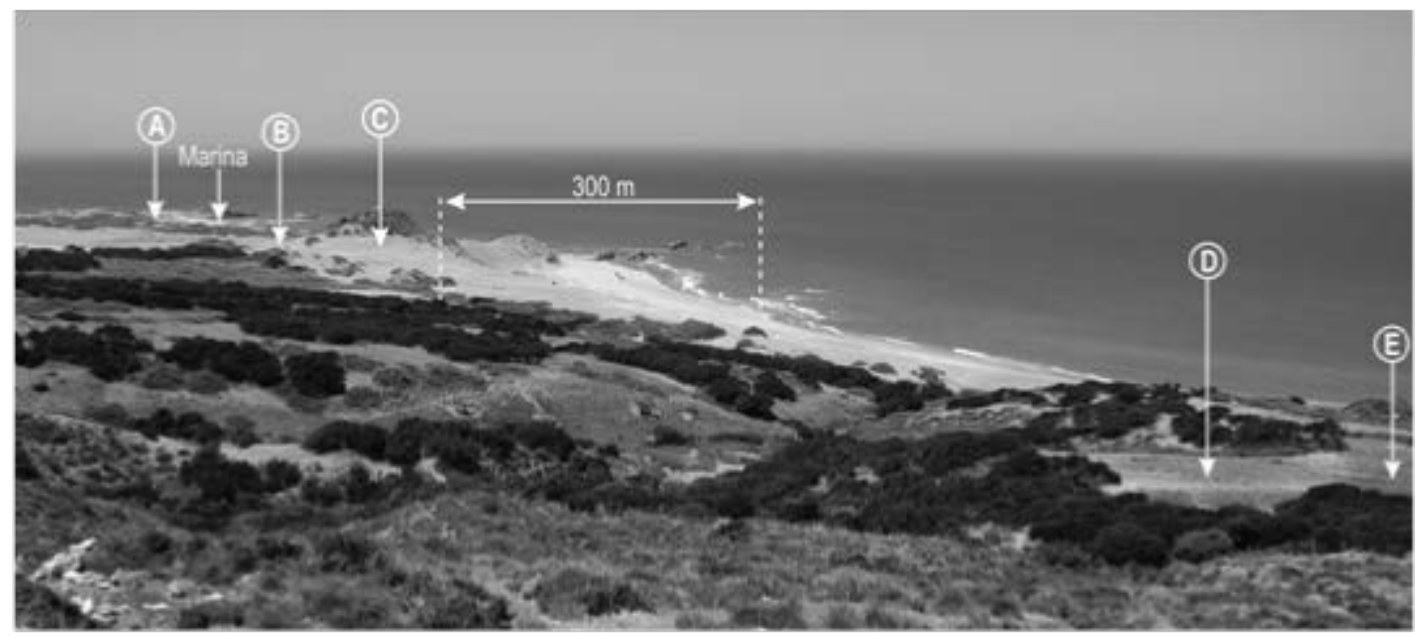

Fig. 5: Programmed accommodations (A-E) in the pristine beach of Cap Ivi (C) 2016 TAIBI).

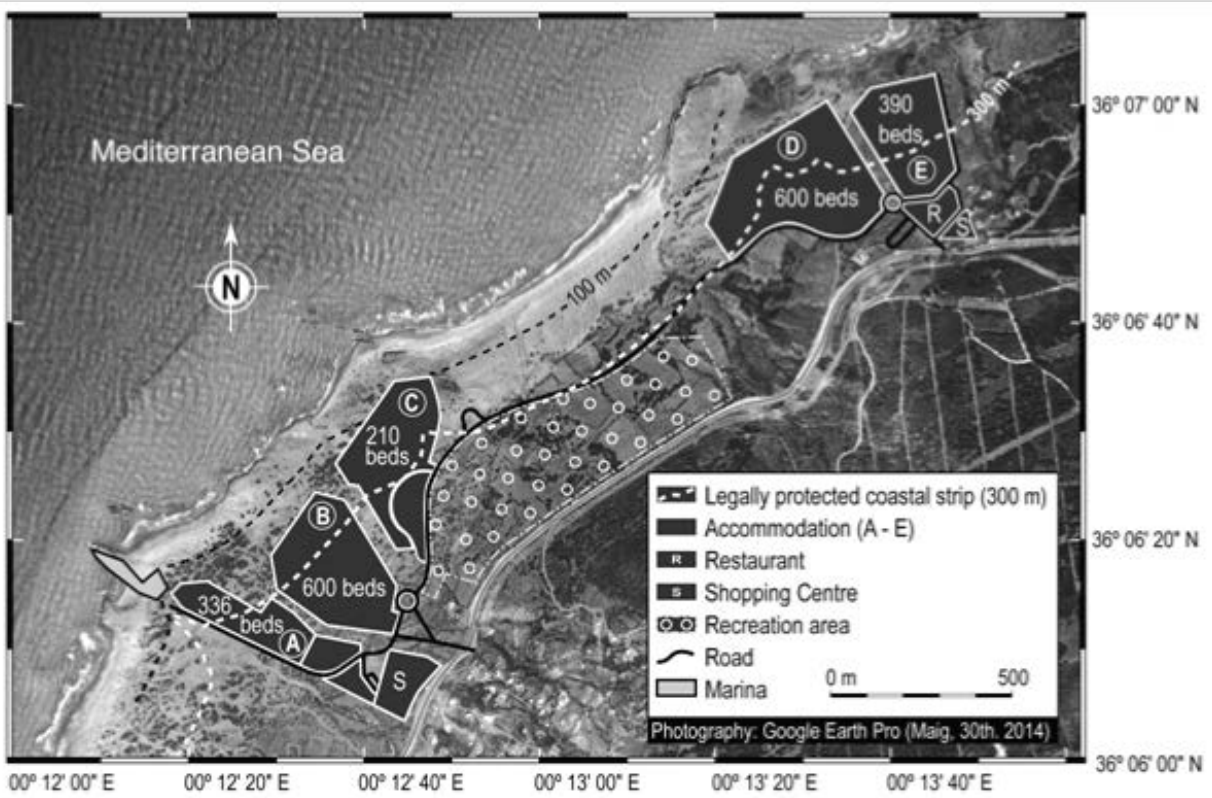

Fig. 6: Construction plan for the beach of Cap Ivi (Executive Decree $\left.n^{\circ} 13-128,2013\right)$. 


\subsection{Coastline urbanization impacts}

Since the sixteen's, seaside tourism is related to coastline urbanization making the reach of the bathing area easier for the tourists. The presence of host accommodations at the beach is an obstacle that slows down the dune formation and the sediment transit between the shoreline and the fore dunes (Hayes et al. 1972; Law \& Davidson-Arnott, 1990; Sherman \& Bauer 1993; Davidson-Arnott 2010). According to Psuty (2004) and Saye et al. (2005), the beach and the dunes are linked in terms of sediment budget. Accordingly, the dune destruction leads in the long term to instability and regression of the fore shore. The pristine beaches of the Eastern coast of Mostaganem represent a vulnerable, raw substance that should be exploited with care preserving them from an excessive urbanization. Beach studies in Estonia and Bulgaria demonstrated that accelerated urbanization and anthropogenic pressure on the coast led to dune sand reduction (Stancheva et al. 2011). Therefore, it's a risk to build in Mostaganem extensive host accommodations close to the coastline; this could be prejudicial to the beach integrity (erosion and sediment budget imbalance). The consequence would be the decrease of capacity and attraction of the beach, and the resulting economic losses. Moreover, the experience of Turkey showed that hotels and secondary housing cooperatives have been built on the coastline in detriment of the fertile agricultural land (Burak et al. 2004). In the case of the Eastern coast of Mostaganem, whose economy is based on agriculture, there is a danger that the construction of accommodations leads to a reduction of the available agriculture fields.

\subsection{Wastewater issue}

Coastline urbanization and lack of wastewater treatment plants signify inevitably a direct wastewater discharge into the sea. Consequently, the high water consumption by the tourists and the insufficient wastewater depuration leads to the degradation of the quality of the bathing waters (Martínez 2003). Moreover, the Spanish experience showed how relevant are wastewater treatment plants (WTP) for the seaside tourism economy. The pollution of the bathing waters of the "Costa del Sol" (Spain) led in 2013 to the lost of its Blue Flag (certified by the Foundation for Environmental Education) (Lerena 2013). In the study case, the Eastern coast of Mostaganem has one lagoon system for wastewater treatment in Hadjadj and two WTP in Sidi Lakhdar and Khadra for altogether 45.000 inhabitants (Directorate of Water Resources 2015). Mentioned WTP are located approximately $20 \mathrm{~km}$ from the programmed host accommodations and their treatment capacity is not sufficient for additional wastewater, which would be produced by the tourists in this area. It is surprising that, the wastewater issue was not enough discussed while planning the touristic projects and the impact assessment did not act consequentially on this matter. This situation would imply a direct wastewater discharge into the sea as happened in the early past in the Western coast of Mostaganem; beaches have been closed due to the water eutrophication caused by excessive urban wastewater discharges (Ahcene-Djaballah 2008). 


\subsection{Which tourism concept in Mostaganem?}

According to the Ministry of Land-use Planning, Tourism, and Handicraft (2015), the number of tourists (11 million) in Mostaganem is significantly higher than the number of the available beds (10.973 beds). How can this inadequacy between supply and demand be solved? The construction of new tourist accommodations is necessary, however, it is essential to take into consideration the distance between the construction site and the coastline. The coastal zone is a limited resource that produces at the same time a use- and an economic value. Therefore, it is relevant to have constantly an anticipated long-term vision for every coastal project. The French Littoral Law stipulates that the extension (urbanization) of the coastal municipalities has to come true in the continuity of the existing agglomerations or should be integrated in the environment (French Directorate of Urbanism, Habitat and Construction 2006). The current trend of the tourism development in Mostaganem seems to follow the Spanish tourism concept. The offer "beach and sun" led in Spain to mass tourism industry and an impressive coastline urbanization. The consequence was the destruction of the fore dunes (GomezPina et al. 2002) and other coastal environmental issues.

From thirteen sandy beaches ( $29 \mathrm{~km}$ coastline) of the Eastern coast of Mostaganem, eight are pristine (Table 2), with forest, extensive dune landscape, and a long coastline $(22 \mathrm{~km})$. These valuable resources could be exploited, however with care because they are sensitive to the urbanization. The proposed concept in this paper is to develop the tourism, building the necessary host accommodations in the nearby-situated rural municipalities. The aim of the concept "beach-rural municipality-accommodation" is to preserve the coastline from the urbanization. How would the concept work? During the day, the tourists would take advantage of the beach and the sea, and at the end of the day, they would return to their accommodation in the nearby rural municipality. A special transportation connecting every beach and the rural municipality, it belongs to would assure the mobility of the tourists. The arguments, which lead to such a concept are: a) the extraordinary ecological value of the region, which has to be preserved, b) the availability of coastal, rural municipalities, c) the distance beach-rural municipality (Table 2), d) the opportunity to involve the local population in the tourism and e) the agricultural activities, which are a basic economic sector in the region and whose products could be efficiently marketed thanks to tourism. This concept would contribute to the local socioeconomic development by diversifying the services and creating employment. Accommodations, respecting the urban style of the rural municipality could be built for the tourists. Abandoned "colonial" farms could be redesigned as touristic accommodations. The creation of natural parks, could complement the touristic offer. This concept is congruent with various forms of sustainable coastal tourism in the Province of Mostaganem (rural, agro-, eco-, and historical tourism). 
Table 2-Beaches and associated rural municipalities (Eastern Coast of Mostaganem)

\begin{tabular}{|l|l|l|l|l|l|}
\hline $\begin{array}{l}\text { Beach (from } \\
\text { West to East) }\end{array}$ & Pristine & $\begin{array}{l}\text { Coastline } \\
\text { urbanization }\end{array}$ & $\begin{array}{l}\text { Coastline } \\
\text { length (km) }\end{array}$ & $\begin{array}{l}\text { Next } \\
\text { municipality (R.M.) }\end{array}$ & $\begin{array}{l}\text { Distance beach } \\
\text { - R.M. (km) }\end{array}$ \\
\hline Cap Ivi & $\square$ & & 4,45 & B. A. Ramdane & 5,5 \\
\hline El Marsa & $\square$ & & 1,78 & B. A. Ramdane & 4,90 \\
\hline Clovis & $\square$ & & 1,42 & B. A. Ramdane & 4,60 \\
\hline Hadjadj I & + & 2,10 & Hadjadj & 7,00 \\
\hline Hadjadj II & $\square$ & & 5,64 & Hadjadj & 7,30 \\
\hline Kaf Lesfar & $\square$ & & 0,83 & Sidi Lakhdar & 3,20 \\
\hline Petit Port & + & 2,61 & P. Port/Sidi Lakhdar & $0,40 / 7,50$ \\
\hline Ain Brahim I & & ++ & 0,38 & Sidi Lakhdar & 11,00 \\
\hline Ain Brahim II & & + & 0,99 & Sidi Lakhdar & 11,40 \\
\hline Zerifa & $\square$ & & 0,25 & Khadra & 6,80 \\
\hline Kef Kaddous & $\square$ & & 0,32 & Khadra/Achaacha & $6,1 / 8,50$ \\
\hline Sidi Abdelkader & & + & 1,27 & Achaacha & 10,60 \\
\hline Bahara & $\square$ & & 7,00 & Ouled Boughalem & 2,90 \\
\hline
\end{tabular}

$\square P \square \mathbb{R I I D ~ b e d a d s o m e ~ b u n g a l o w s , ~ + + ~ E d i f i c a t i o n ~ f o r ~ l o c a l ~ p o p u l a t i o n ~ a n d ~ t o u r i s t ~ a c c o m m o d a t i o n s . ~}$

It is also important to emphasize that the stewardships will not emerge if the local population perceives high costs associated with tourism activities and protected area restrictions (Lindberg \& Enriquez 1994). Likewise, if the decision makers do not involve the local population, a sustainable tourism will fail and can even be detrimental to local communities (Ziffer, 1989). According to Müller (2007), ecotourism ensures the environment protection, however it cannot totally liberate the local communities from poverty. Indeed, it can harm the environment and deprive the local population, even further if the economic interests would predominate. In the era of both economic development and environmental protection, developed countries make efforts to protect legally their natural areas, saving them from the urbanization and the pollution. Considering that its natural heritage is still conserved and its tourism is underdeveloped, Algeria should take advantage of that experience, to be able to make correct decisions by sensitive issues. Regrettably, construction of host accommodations was authorized close to the coastline in Algeria. This issue is inconsistent with the National Tourism Development Plan for 2015-2025 (SDAT 2008), which clearly stipulates that tourism projects will be carried out only by considering the environmental sustainability (Law 0301 2003). Unfortunately, in the practice, the decisions are made in haste and the 
feasibility assessment is often fragmentary. It is surprising that natural reserves and campsites that would be appropriated for the natural coastal areas as those of Mostaganem are superficially mentioned in the SDAT (2008). Local authorities have not only to gauge the best use, but also to recognise and apply the management strategies required to ensure a sustainable usage (McLachlan et al. 2013).

\section{Conclusion}

The Algerian oil and gas incomes decreased almost in half: US $\$ 33,8$ billion for, 2015 against US\$ 66 for 2014 (CNIS 2015). For this reason, the economic conjuncture urges the country to create other sources of wealth to ensure its development. For the Algerian Government, the tourism is one of the priorities as mentioned in the National Tourism Development Plan (SDAT 2008). The construction of new tourists accommodations and facilities is essential for the tourism promotion. It is also relevant to consider its feasibility because the coastal zone is sensitive to anthropogenic transformation. The beaches are the basis for the seaside tourism, that's why only a sustainable development of this activity can guarantee steady incomes. The Spanish concept "beach and sun" showed since the seventies, that mass tourism is economically profitable, but it's at the same time the principal reason for the coast deterioration.

Nowadays, tourist accommodation projects have been approved throughout the Algerian coast after hastily made decisions. The Algerian juridical arsenal for coastal protection is respectable, but it finds difficulties in the practice to be fully implemented. The dismal issue is the disrespect of the legally protected $300 \mathrm{~m}$ coastal strip (Littoral Law 02/2002). It is regrettable that construction projects for tourist accommodations have been authorized in ecologically sensitive coastal sites, as Cap Ivi and the beach of Ben Abdelmalek Ramdane (Eastern coast of Mostaganem). Furthermore, the wastewater issue has not been enough discussed in spite of the lack of wastewater treatment plants (WTP) in this coastal area. According to the Directorate of Water Resources (2015), one WTP is operational in Sidi Lakhdar for 35.000 inhabitants) and another one in Khadra for 10.000 inhabitants). The four remaining coastal municipalities (B.A. Ramdane, Hadjadj, Achaacha and Ouled Boughalem) have no WTP although they belong to legally established Touristic Expansion Zones (TEZ). The Spanish experience showed that excessive wastewater had to be discharged directly into the sea, disturbing the quality of the bathing waters (Taibi 2014). In the case of Mostaganem, the wastewater issue could be a serious problem for the tourism quality. In the near future, the decision makers should pay special attention for the wastewater issue planning tourist accommodations. If the seaside tourism profitability would be successful in Algeria and the decision makers would continue to transgress the established Littoral law, the massive urbanization of the coastline would be only a question of time. Besides agriculture, other coastal activities as eco-tourism, rural tourism, or agro-tourism would be an alternative for the economic development of Algeria; they are appropriated for natural areas as plenty available in the country. The Eastern coast of Mostaganem is a paradigmatic example; it provides a remarkable natural, cultural, and historical heritage. The associated rural municipalities, located on the ledge, have existed for years and its population depends on agriculture. These are excellent predispositions to invest in several forms of 
sustainable tourism involving the local populations. The concept "beach-rural municipality-accommodation" can benefit both the economy and the environment. In this regard, Algeria should take all the necessary measures to ensure a consequent application of the already existing Littoral law while developing the coastal zone.

\section{Acknowledgements}

We thank the Algerian Ministry of Land-use Planning, Tourism, and Handicraft, the Directorate of Water Resources and the Directorate of Environment (Province of Mostaganem) for their support.

\section{References}

Ahcene-Djaballah, B. (2008, May 11) Littoral. Almanach-DZ. Available at: http://www.almanach-dz.com/index.php?op=fiche\&fiche=492 (Accessed on October, 3rd 2015)

Blancas, F.J., Lozano-Oyola, M., González, M., Guerrero, F.M. \& Caballero, R. (2011) How to use sustainability indicators for tourism planning: The case of rural tourism in Andalusia (Spain). Science of the Total Environment, 412-413, 28-45

Bouadam, K. (2011) The national strategy of tourism development in Algeria, issues, opportunities and limitations. Review of applied socioeconomic research, (2), 23-37

Burak, S., Dog, E. \& Gaziog, C. (2004) Impact of urbanization and tourism on coastal environment, Ocean \& Coastal Management (47), 515-527

CNIS (2015) Ministère des Finances/ Douanes, Statistiques du commerce extérieur de l'Algérie, 2014. Centre National d'Informatique et Statistiques, 17. Available at: http://www.douane.gov.dz/pdf/r_periodique/Annee\%202015.pdf (Accessed on October, 11th 2015)

Davidson-Arnott, R.G.D. (1988) Temporal and spatial controls on beach/ dune interaction, Long Point Lake Erie. Journal of Coastal Research, Spec; The Coastal Education and Foundation CERF, Charlottesville, 131-136

Davidson-Arnott, R.G.D. (2010) Introduction to coast processes and geomorphology, Cambridge University Press, United Kingdom, $442 \mathrm{p}$

Decree 88-232 (1988) Available at: http://www.andtdz.org/baoff/fichiers/fichiers/fichiersesma26093841351420382886.pdf (Accessed on January, 17 th 2016)

Decree 10-131 (2010) Available at: http://www.joradp.dz/FTP/jo-francais/2010/F2010030.pdf (Accessed on January, 17th 2016)

Directorate of Urbanism, Habitat and Construction (2006) Direction Générale de l'Urbanisme, de l'Habitat et de la Construction. Les principes d'aménagement du littoral. Available at: www.urbanisme.equipement.gouv.fr (Accessed on May, 10th 2016)

Directorate of Water Resources, Province of Mostaganem (2015) Realization of 3 Wastewater Treatment Plants in Sidi Lakhdar, khadra and Sidi Ali, Operation reference: NF 534262621270609

Executive Decree n¹3-128 (2013) Ministry of Land-use Planning, Tourism and Handicraft. April 6th, 2013. Available at: http://www.andt-dz.org/ (Accessed on May, 9th 2016)

Gomez-Pina, G., Muñoz-Perez, J.J., Ramirez, J.L. \& Ley, C. (2002) Sand management problems and techniques, Spain, Journal of Coastal Research, (36), 325-332

Google Earth Pro (2015) Version 7.1.5.1557, Coastal zone of Mostaganem

Google Earth Pro (2015) Photography of Cap Ivi Beach, Eastern coast of Mostaganem (Accessed on February, 19th 2016)

Hayes, M., Owens E, Hubbard D, Abelle R (1972) The investigation of form and process in the coastal zone. Coates D (ed.). Coastal Geomorphology, (A), State University of New York, 11-41.

Informe anual de Ecologistas en Acción (2005) Banderas negras en las playas del sur de España, Spain. 
Fedra, K. (2004) Coastal zone resource management: tools for a participatory planning and decision making process. Littoral 2004, 20-22 September. Aberdeen, Scotland, UK. 1

Law 2003-01 2003 Loi 2003-01 du 17 février 2003, relative au développement durable du tourisme 6 p. Available at: http://www.andtdz.org/baoff/fichiers/fichiers/fichiersesma10751113351420361367.pdf (Accessed on May, 9th 2016)

Law, M.N. \& Davidson-Arnott, R.G.D. (1990) Seasonal controls on aeolian process on the beach and foredune. Proc. Can. Symp., On Coast. Sand Dunes, 49-68

Lerena, J. (2013) Las playas de la Costa del Sol pierden seis banderas azules. La opinion de Malaga, Spain (Accessed May 25th 2015)

Lindberg, K. \& Enriquez, J. (1994) An analysis of ecotourism's economic contribution to conservation \& development in Belize. Washington DC: World Wildlife Fund (2)82 p.

Littoral Law 02-2002 Loi relative à la Valorisation et la Protection du littoral. 5 février 2002, 7 p. Available at: http://www.jijel-archeo.123.fr/droit_algerien/loi_dz/loi0202.htm (Accessed on November, 15th 2015)

McLachlan, A., Defeo, O., Jaramillo, E. \& Short, A. (2013) Sandy beach conservation and recreation: Guidelines for optimising management strategies for multi-purpose use. Ocean and Coastal Management, 71, 256-268

Martínez, I. (2003) La afluencia masiva de visitantes dispara el consumo de agua en la Costa del Sol", Málaga, El País. Archivo, 27 July 2003

Ministerio de Industria, Energía y Turismo (2014) Frontur, noviembre 2014, http://estadisticas.tourspain.es/es-ES/Paginas/default.aspx? (Accessed on October, 20th 2015)

Ministry of Land-use Planning, Tourism, and Handicraft (2015) Algeria. Available at: http://www.okbob.net/article-le-site-officiel-du-ministere-du-tourisme-et-de-l-artisanat-algerie89361166.html (Accessed on October, 5th 2015)

Müller, F.G., (2000) Ecotourism: an economic concept for ecological sustainable tourism, International Journal of Environmental Studies, 57(3), 241-251

Protection civile de Mostaganem (2015) Statistiques baigneurs, plages de Mostaganem

Psuty, N. P. (2004) The coastal foredune: a morphological basis for regional coastal dune development, in Martínez, M. L. and Psuty, N. P. (editors) Coastal Dunes: Ecology and Conservation, Ecological Studies (171), Springer, Berlin, 11-28

Saye, S.E., Van der Wal, D., Pye, K. \& Blott, S.J. (2005) Beach -dune morphological relationships and erosion/accretion: An investigation at five sites in England and Wales using LIDAR data. Geomorphology (72), 128-155

SDAT (2008) Schéma directeur d'aménagement touristique 2025. Livre $\mathrm{N}^{\circ}$ 5, Les projets touristiques prioritaires. Ministère de l'aménagement du Territoire, de l'Environnement et du Tourisme. Janvier 2008, Available at: http://www.andtdz.org/baoff/fichiers/fichiers/fichiersesma7659760911422971095.pdf (Accessed on May, 12th 2016)

Sherman, D.J. \& Bauer, B.O. (1993) Dynamics of Beach-Dune Systems, Progress in Physical Geography, 17(4), 413-447

Stancheva, M., Ratas, U., Orviku, K., Palazov, A., Rivis, R., Kont, A., Peychev, V., Tõnisson, H. \& Stanchev, H. (2011) Sand Dune Destruction Due to Increased Human Impacts along the Bulgarian Black Sea and Estonian Baltic Sea Coasts, Journal of Coastal Conservation, SI 64, 324-328.

Taibi, N. (2014) Impacts du tourisme de masse sur les plages. Expérience de l'Espagne (Méditerranée). Journal of marine sciences and coastal research 1, 33-55

Ziffer, K. (1989) Ecotourism: the uneasy alliance. Working Paper Series. International conservation. $36 \mathrm{p}$ 
